Australian Journal of

Crop Science

AJCS

AJCS 13(10):1650-1658 (2019)

ISSN:1835-2707

doi: 10.21475/ajcs.19.13.10.p1889

\title{
Mineral composition and nutritive value of Festuca ecotypes originated from the highland region of Bolivia and cultivars from Argentina
}

\author{
Karina Ustariz ${ }^{1 *}$, Mulatu Geleta ${ }^{1}$, Helena P. Hovmalm ${ }^{1}$, Franz Gutierrez ${ }^{2}$, Jorge A. Rojas Beltrán ${ }^{3}$, Rodomiro \\ Ortiz $^{1}$
}

${ }^{1}$ Department of Plant Breeding, Swedish University of Agricultural Sciences, Box 101, SE-23053, Alnarp, Sweden

${ }^{2}$ Centro de Investigación en Forrajes (CIF) - La Violeta, Facultad de Ciencias Agrícolas, Pecuarias y Forestales “Dr. Martín

Cárdenas", Universidad Mayor de San Simón, Cochabamba, Bolivia

${ }^{3}$ Centro de Biotecnología y Nanotecnología Agropecuario y Forestal (CByNAF), Facultad de Ciencias Agrícolas, Pecuarias y Forestales "Dr. Martín Cárdenas", Universidad Mayor de San Simón, Cochabamba, Bolivia

*Corresponding author: karinaustariz@slu.se; karinaustariz@hotmail.com

\begin{abstract}
Native grasses constitute the most important source of feed for camelids, sheep and cattle in the highlands of Bolivia, where the genus Festuca is one of the major feed components. This study was carried out to investigate the nutritional value of 11 Festuca ecotypes from the highlands of Bolivia and two cultivars from Argentina (Festuca arundinacea Schreb. cv. 'Taita' and Festulolium). All ecotypes were grown in the same experimental field and their protein, ash, cellulose, moisture and micronutrients ( $\mathrm{Al}, \mathrm{B}, \mathrm{Ca}, \mathrm{Cd}, \mathrm{Cu}, \mathrm{Fe}, \mathrm{K}, \mathrm{Mg}, \mathrm{Mn}$, $\mathrm{Mo}, \mathrm{Na}, \mathrm{Ni}, \mathrm{P}, \mathrm{S}, \mathrm{Si}$ and $\mathrm{Zn}$ ) content was determined. Principal component analysis and unweighted pair group method with arithmetic mean (UPGMA) cluster analysis, based on all nutrients, clearly defined the two Argentinian cultivars as outliers. This differentiation was mainly explained by their cellulose, ash, $\mathrm{Mn}$ and Al contents. Analysis of variance based on the origin of the accessions revealed highly significant $(P<0.001)$ differences for their cellulose, ash, $\mathrm{Mn}$ and $\mathrm{Mg}$ contents, while they differ significantly $(P<0.05)$ in $\mathrm{Ni}$, Fe, $\mathrm{Na}$ and Al contents. There was a highly significant positive correlation between several pairs of minerals including $\mathrm{Mg}-\mathrm{Ca}(r=0.94)$ and $\mathrm{Mg}-\mathrm{Zn}$ $(r=0.92)$. Negatively correlated pairs of minerals include B-Fe $(r=-0.65)$ and $B-N i(r=-0.58)$. This study provides useful information about the nutritive quality of Bolivian Festuca ecotypes for their use in breeding programs of this forage grass in the Andean highlands of South America.
\end{abstract}

Keywords: Fescue, forage, micronutrient, principal component analysis.

Abbreviations: ICP-OES_Inductively Coupled Plasma Optic Emission Spectrometry; PCA_Principal Component Analysis; UPGMA_ unweighted pair group method with arithmetic mean.

Introduction

The Andean region of Bolivia comprises about $200000 \mathrm{~km}^{2}$ with an altitudinal range between 3600 and $4300 \mathrm{~m}$ above sea level (masl) and is characterized by climatic stress including drought and frost as well as unfavorable soil conditions (Geerts et al., 2006). The main activity of farmers is livestock production, where llamas (Lama glama) are the most common, constituting around $63 \%$ of the South American llama population (Markemann et al., 2009). This animal is generally kept together with sheep in the farming systems playing an important role in the sustainability as it is less susceptible to widespread climatic risks than crops (Camino and Sumar, 2000; Campero, 2004).

The most important feed sources for camelids and ruminant species are native grasslands (Genin and Alzérreca, 2006) that include several unique plant communities adapted to the adverse climate conditions in the area. Among these, "pajonales" occupy extensive areas and are represented by tall and coarse bunchgrasses of the Stipa, Festuca and Callamagrostis genera (Genin et al., 1994; Sumar, 2010). Festuca orthophylla Pilg., known as "paja brava" or "iru ichu" is the most widespread grass in the highlands of Bolivia, occupying almost $30 \%$ of the central area (Alzérreca and Lara, 1988; Monteiro et al., 2011). It is considered as the major component of feed preferred by camelids, especially llamas, despite being a poor forage due to its roughness and very low nutritive value (Genin et al., 1994; Zapata, 2005; Monteiro and Körner, 2013).

Despite the fact that the majority of the grass species in the native grasslands are considered as having low nutritive value, farmers believe that natural grasslands of Festuca 
dolichophylla J. Presl. also known as "chilliwar" rangelands are a very important source of feed, especially for cattle, llamas and sheep (Mercado et al., 2013). The presence of various associated plant species such as layu (Trifolium amabile), sillu sillu (Lachemilla pinnata), siqui (Hypochaeris spp.), cebadilla (Bromus catharticus), cola de ratón (Hordeum muticum), chiji blanco (Distichlis humilis), kemallu (Eleocharis spp.), poita (Poa annua) and chiji negro (Muhlenbergia fastigiata) improves the forage value of these rangelands (Martínez et al., 2004; Genin and Alzérreca, 2006). However, the rangelands are suffering from a continuous degradation of the soil, narrowing of its range due to the advancing agricultural frontiers and overgrazing (Alzérreca, 2004).

Improvement of livestock outputs requires an efficient use of available feed resources. The nutritive value of forage species is however affected by genetic variation, climate, agronomic practices and feed processing technologies (Khan et al., 2007). Besides nutritive values that can be obtained by measuring crude protein content, acid detergent fiber, neutral detergent fiber and ash, forages are an important source of minerals for ruminants and camelids. In some cases, forages provide adequate quantities of all essential minerals, but in others, they may be deficient in one or more minerals, thus supplementation is required for optimal performance and health of the animals (Spears, 1994; Givens et al., 2000).

The bioavailability of major and minor essential elements, as well as trace elements constitute the cornerstone for increasing the performance and health of grazing livestock (National Research Council, 2007). The mineral content of forages depends on the interaction of a number of factors including soil, forage species, stage of maturity and pasture management. In addition, climate affects plant growth rate and plant maturity, thereby altering mineral content (Givens et al., 2000). Hence, the bioavailability of minerals is also an important consideration when evaluating dietary adequacy (Lewis and Bayley, 1995).

There is scant research on botanical composition and nutritional value of native grasslands in the highland region of Bolivia (Alzérreca and Cardozo, 1991; Mamani-Linares et al., 2013). Thus, a comprehensive study on the nutritional value of Bolivian Festuca species, which are the most important native forage grasses in Bolivia, is essential. The main goal of this research was to assess different Festuca ecotypes for protein, cellulose, ash and mineral composition in order to identify promising candidates for future use in breeding programs.

\section{Results}

\section{Nutritional content and mineral composition}

Significant differences in ash and cellulose content were found among Festuca ecotypes from Bolivia and cultivars from Argentina (Table 1). Ash content ranged from 7.3\% (Accession 27 ) to $16.5 \%$ (Accession 44). The two Argentinian cultivars, $F$. arundinacea cv. 'Taita' and Festulolium had the highest ash content with $16.5 \%$ and $14.3 \%$ respectively, followed by the Bolivian accessions 19 (9.7\%) and 38 (9.5\%). Cellulose content ranged from $18.7 \%$ (accession 44) to $33.6 \%$ (accession 27). Accessions 9 and 19 also showed quite high cellulose content,
$33.4 \%$ and $33.3 \%$, respectively. The protein content obtained with the organic elemental analyzer (OEA) ranged from $6.7 \%$ (accessions 38 and 27) to $12.2 \%$ (accession 29) and protein content obtained with the Kjeldahl method ranged from $6.1 \%$ (accession 38) to $12.4 \%$ (accession 45). Both methods showed that accessions 29 and 45 were the top two in protein content among the accessions studied. When a comparison between origins was performed, ash and cellulose content showed highly significant differences $(P<0.001)$, but the differences for both protein and moisture were not-significant $(P>0.05)$. Results were very similar when comparing the averages of the micronutrients of Bolivian ecotypes and Argentinian cultivars (Table 2).

The Argentinian F. arundinacea cv. 'Taita' (accession 44) had the highest $\mathrm{Mg}, \mathrm{Fe}, \mathrm{Mn}$ and $\mathrm{Al}$ content, while Festulolium (accession 45) had the highest $\mathrm{Ca}, \mathrm{P}, \mathrm{Na}, \mathrm{K}, \mathrm{S}$, and $\mathrm{Zn}$ content (Table 2). Among the Bolivian ecotypes, accessions 32, 21 and 10 were the top three in terms of $\mathrm{Ca}\left(\geq 2795 \mathrm{mg} \mathrm{kg}^{-1}\right)$ and $\mathrm{Mg}(\geq$ $1590 \mathrm{mg} \mathrm{kg}^{-1}$ ) content, while accessions 38,29 and 23 were at the top in terms of their $P$ content $\left(\geq 1550 \mathrm{mg} \mathrm{kg}^{-1}\right)$. Interestingly, accessions 41 and 43 showed more than a twofold higher $\mathrm{Na}$ content $\left(\geq 160 \mathrm{mg} \mathrm{kg}^{-1}\right.$ ) than other Bolivian ecotypes, whereas accession 21 and 29 had the highest $\mathrm{S}$ content ( $\geq 1600 \mathrm{mg} \mathrm{kg}^{-1}$ ) and accession 23 and 29 the highest $\mathrm{K}$ (12000 mg kg-1) content. Accession 27 showed the lowest $\mathrm{Ca}$ (1890 mg kg-1), P (886 mg kg-1), K (6400 mg kg-1), S (800 mg kg $\left.{ }^{1}\right), \mathrm{Zn}\left(11 \mathrm{mg} \mathrm{kg}^{-1}\right)$ and $\mathrm{Mn}\left(29 \mathrm{mg} \mathrm{kg}^{-1}\right)$ content (Table 2).

\section{PCA analysis and UPGMA clustering of the nutritional values by origin}

The Principal Component Analysis (PCA) based on mineral and nutrient content data showed good reproducibility between technical laboratory replicates per accession.

The two outliers were the Argentinian cultivars $F$. arundinacea cv. 'Taita' (accession 44) and Festulolium (Accession 45), which were clearly separated from the Bolivian ecotypes (Figure 1). The ecotypes from Cochabamba and La Paz were clustered together, which could be explained by their lower content of protein (except for accession 21), $\mathrm{Ca}, \mathrm{Mg}$ and $\mathrm{Cu}$ (except for accession 43). Similarly, the clustering among ecotypes from Oruro and Potosí could be explained by their higher content of protein, $\mathrm{Ca}, \mathrm{Mg}$ and $\mathrm{Zn}$ as compared with the other Bolivian ecotypes (Figure 1).

According to the PCA (Table 3), the first two PCs together explained $69.9 \%$ of all the nutrients variability among the accessions. The first PC explained $48 \%$ of the total variation, mainly due to differences in $\mathrm{Mg}, \mathrm{Ca}, \mathrm{Zn}, \mathrm{Mn}$, cellulose, $\mathrm{S}$, ash, $\mathrm{K}, \mathrm{Fe}, \mathrm{P}$, moisture and $\mathrm{Al}$ contents. The traits that contributed more to differentiation at the second PC, which accounted for $21.9 \%$ of the total variation, were $\mathrm{Cu}, \mathrm{Cd}$ and protein content. These results indicate that $\mathrm{Mg}, \mathrm{Ca}, \mathrm{Zn}, \mathrm{Mn}$, cellulose, $\mathrm{S}$, ash, $\mathrm{K}$, $\mathrm{Fe}, \mathrm{P}$, moisture, $\mathrm{Al}, \mathrm{Cu}, \mathrm{Cd}$ and protein are of primary importance in differentiating accessions.

Cluster analysis based on UPGMA method resulted in a clear grouping of the accessions into two major clusters, with the first cluster further separated into two sub-clusters (Figure 2). Sub-cluster IA included ecotypes from La Paz and Cochabamba (accessions 27, 38, 41, 9 and 19), which are characterized by a 
Table 1. Nutrient content and moisture of Festuca Bolivian ecotypes and Argentinian cultivars

\begin{tabular}{|c|c|c|c|c|c|c|}
\hline Accession & Origin & $\begin{array}{l}\text { Ash } \\
\text { (\%) }\end{array}$ & $\begin{array}{l}\text { Cellulose } \\
\text { (\%) }\end{array}$ & $\begin{array}{l}\text { Protein-1 } \\
\text { (\%) }\end{array}$ & $\begin{array}{l}\text { Protein-2 } \\
\text { (\%) }\end{array}$ & $\begin{array}{l}\text { Moisture } \\
\text { (\%) }\end{array}$ \\
\hline 9 & Cochabamba & 7.5 & 33.4 & 7.8 & 8.1 & 53.1 \\
\hline 23 & Cochabamba & 7.8 & 31.8 & 8.1 & 8.7 & 58.9 \\
\hline 38 & Cochabamba & 9.5 & 30.6 & 6.1 & 6.7 & 44.6 \\
\hline 41 & Cochabamba & 8.9 & 30.9 & 6.8 & 7.2 & 50.9 \\
\hline 43 & Cochabamba & 8.4 & 29.8 & 9.6 & 9.9 & 50.6 \\
\hline 19 & La Paz & 9.7 & 33.3 & 7.8 & 8.2 & 53.8 \\
\hline 21 & La Paz & 8.8 & 29.3 & 10.3 & 10.2 & 56.7 \\
\hline 27 & La Paz & 7.3 & 33.6 & 6.3 & 6.7 & 35.5 \\
\hline 10 & Oruro & 9.2 & 32.8 & 11.5 & 11.5 & 55.6 \\
\hline 29 & Potosi & 8.1 & 28.3 & 12.1 & 12.2 & 58.4 \\
\hline 32 & Potosi & 9.3 & 27.6 & 10.0 & 10.1 & 51.3 \\
\hline 44 & Argentina & 16.5 & 18.7 & 6.8 & 7.7 & 55.4 \\
\hline 45 & Argentina & 14.3 & 20.3 & 12.4 & 11.8 & 66.1 \\
\hline Comparison between origins ( $P$-value) & & $<0.001$ & $<0.001$ & n.s. & n. s. & n. s. \\
\hline Bolivian ecotypes, average & & $8.6 \mathrm{~b}$ & $31.0 \mathrm{a}$ & $8.8 \mathrm{a}$ & $9.0 \mathrm{a}$ & $51.8 \mathrm{a}$ \\
\hline Cultivars from Argentina, average & & $15.4 \mathrm{a}$ & $19.5 b$ & $9.6 \mathrm{a}$ & $9.8 \mathrm{a}$ & $60.8 \mathrm{a}$ \\
\hline
\end{tabular}

Protein-1: corresponds to the concentration obtained with the Kjeldahl method. Protein-2 corresponds to the concentration obtained using the organic elemental analyzer.

The probability $(P)$ values are for the comparison among accessions within their origin. Different letters within each column indicate a significant difference at $P=0.05$ level, when comparing accessions from Bolivia and cultivars from Argentina.

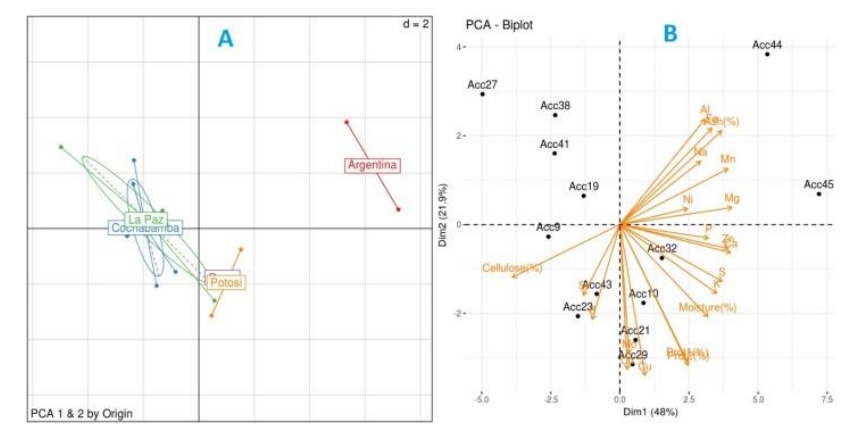

Fig. 1: A) Principal component analysis (PCA) scores plot on aggregated data of ash, cellulose, protein, moisture and micronutrients in Festuca ecotypes and cultivars from Argentina showing how accessions are clustered according to their origin. B) Loadings showing the relationships among variables and with PCs using the average of the two replicates per accession. Dim1 and Dim 2 represent the first and the second principal components, which explain $48 \%$ and $21.9 \%$ of the total variance among the accessions.

Table 2. Mineral element contents of 11 ecotypes from the highlands of Bolivia and two Argentinian cultivars of Festuca

\begin{tabular}{|c|c|c|c|c|c|c|c|c|c|c|c|c|c|c|c|c|c|}
\hline Acc & Origin & $\mathrm{Ca}^{\mathrm{a}}$ & $\mathrm{Pa}$ & $\mathrm{Na}^{\mathrm{a}}$ & $\mathrm{Mg}^{\mathrm{a}}$ & $\mathrm{K}^{\mathrm{a}}$ & $\mathrm{S}^{\mathrm{a}}$ & $\mathrm{Fe}^{\mathrm{b}}$ & $\mathrm{Cu}^{\mathrm{b}}$ & $\mathrm{Zn}^{\mathrm{b}}$ & $\mathrm{Mn}^{\mathrm{b}}$ & $\mathrm{Mo}^{\mathrm{b}}$ & $\mathrm{Al}^{\mathrm{c}}$ & $\mathrm{B}^{\mathrm{c}}$ & $\mathrm{Ni}^{\mathrm{c}}$ & $\mathrm{Si}^{\mathrm{c}}$ & $\mathrm{Cd}^{\mathrm{d}}$ \\
\hline 9 & Cbba & 2505 & 1270 & 60 & 1320 & 10000 & 1000 & 860 & 5.4 & 13 & 33.5 & $1.7^{*}$ & 464 & 22.5 & $1.8^{*}$ & 510 & $<0.13$ \\
\hline 23 & Cbba & 2580 & 1550 & 54 & 1295 & 12000 & 1550 & 785 & 5.2 & 12 & 41.0 & $2.2^{*}$ & 414 & 26.0 & $1.9^{*}$ & 596 & $<0.14$ \\
\hline 38 & Cbba & 2425 & 1720 & 58 & 1105 & 8300 & 1450 & 1100 & 4.4 & 12 & 38.0 & $0.8^{*}$ & 600 & 21.5 & $1.9^{*}$ & 562 & $<0.11$ \\
\hline 41 & Cbba & 2135 & 1420 & 160 & 1265 & 10000 & 1100 & 995 & 4.4 & 12 & 36.5 & $1.0^{*}$ & 543 & 26.0 & $2.0^{*}$ & 513 & $<0.12$ \\
\hline 43 & Cbba & 2355 & 1275 & 205 & 1310 & 11000 & 1500 & 1000 & 7.0 & 14 & 37.5 & $1.8^{*}$ & 520 & 28.5 & $1.4^{*}$ & 488 & $<0.13$ \\
\hline 19 & $\mathrm{LP}$ & 2590 & 1350 & 61 & 1365 & 9250 & 1200 & 1200 & 5.3 & 14 & 35.5 & $1.4^{*}$ & 647 & 21.5 & $2.2^{*}$ & 499 & $<0.13$ \\
\hline 21 & $\mathrm{LP}$ & 3045 & 1545 & 75 & 1600 & 11000 & 1600 & 1100 & 5.9 & 14 & 45.5 & $2.5^{*}$ & 596 & 27.5 & $2.3^{*}$ & 602 & $<0.14$ \\
\hline 27 & LP & 1890 & 886 & 63 & 1200 & 6400 & 800 & 1100 & 4.4 & 11 & 29.0 & $1.4^{*}$ & 590 & 21.0 & $2.1^{*}$ & 496 & $<0.11$ \\
\hline 10 & Oru & 2795 & 1360 & 58 & 1590 & 11000 & 1550 & 1350 & 5.4 & 14 & 38.5 & $2.7^{*}$ & 686 & 18.5 & $3.9 *$ & 570 & $<0.14$ \\
\hline 29 & Pot & 2755 & 1600 & 75 & 1555 & 12000 & 1700 & 825 & 6.9 & 14 & 38.0 & $1.4^{*}$ & 404 & 25.0 & $1.8^{*}$ & 514 & $<0.14$ \\
\hline 32 & Pot & 3060 & 1415 & 78 & 1840 & 9450 & 1400 & 1600 & 6.5 & 16 & 41.5 & $1.6^{*}$ & 830 & 23.5 & $3.2^{*}$ & 518 & $<0.15$ \\
\hline 44 & Arg & 3350 & 1585 & 235 & 2235 & 12000 & 1700 & 2200 & 4.6 & 15 & 74.0 & $1.4^{*}$ & 1130 & 21.0 & $3.0^{*}$ & 514 & $<0.13$ \\
\hline 45 & Arg & 3375 & 2125 & 250 & 2080 & 15000 & 2100 & 1700 & 5.5 & 19 & 65.0 & $1.3^{*}$ & 830 & 20.5 & $2.9^{*}$ & 436 & $<0.11$ \\
\hline $\begin{array}{l}\text { Comparison } \\
\text { origins } \\
(P \text {-value })\end{array}$ & between & n.s. & n.s. & 0.03 & $<0.001$ & n.s & n.s. & 0.02 & n.s. & n.s. & $<0.001$ & n.s. & 0.04 & n.s. & 0.01 & n.s. & n.s. \\
\hline $\begin{array}{l}\text { Bolivian } \\
\text { average }\end{array}$ & ecotypes, & $2558 b$ & $1399 a$ & $86 b$ & $1404 b$ & $10036 a$ & $1350 a$ & $1083 b$ & $5.5 a$ & $13 b$ & $37.7 b$ & $1.7 a$ & $572 b$ & $23.8 \mathrm{a}$ & $2.2 \mathrm{a}$ & $534 a$ & $0.1 a$ \\
\hline $\begin{array}{l}\text { Cultivars } \\
\text { Argentina, av }\end{array}$ & age ${ }^{\text {from }}$ & $3362 a$ & $1855 a$ & $242 a$ & 2158a & $13500 a$ & 1900a & $1950 a$ & $5.0 a$ & $17 a$ & $69.5 a$ & $1.3 a$ & $980 a$ & $20.8 a$ & $3.0 a$ & $474 a$ & $0.1 \mathrm{a}$ \\
\hline
\end{tabular}

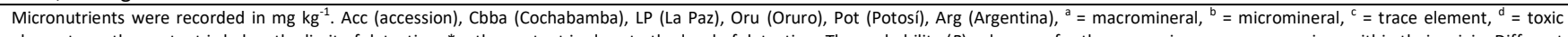
element, $<=$ the content is below the limit of detection, ${ }^{*}=$ the content is close to the level of detection. The probability $(P)$ values are for the comparison among accessions within their origin. Different letters within each column indicate a significant difference at $P=0.05$ when comparing accessions from Bolivia and cultivars from Argentina. 


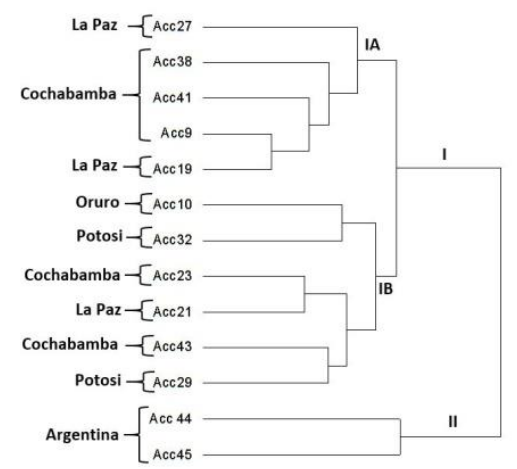

Fig 2. Dendrogram from cluster analysis (UPGMA) of the 11 Bolivian ecotypes and two Argentinian cultivars based on protein, ash, cellulose, moisture and micronutrients content.

Table 3. Principal component (PC) analysis of nutritional value according to the origin of the accessions revealing eigenvalue, total variance, eigenvectors and contribution to total variation explained by the first two PC axes. Ash, cellulose, protein and moisture were recorded in percentage and micronutrients were recorded in $\mathrm{mg} \mathrm{kg}^{-1}$.

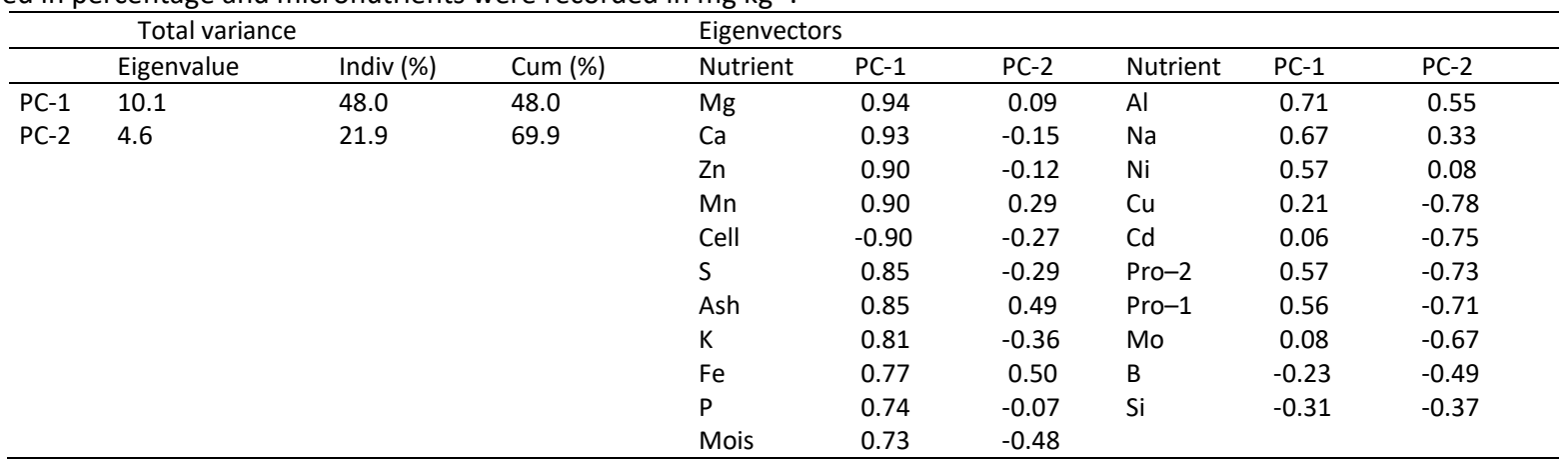

Indiv = individual, Cum = cumulative, Cell = cellulose, Mois = moisture, Pro-2 = protein -2 , Pro-1 = protein-1.

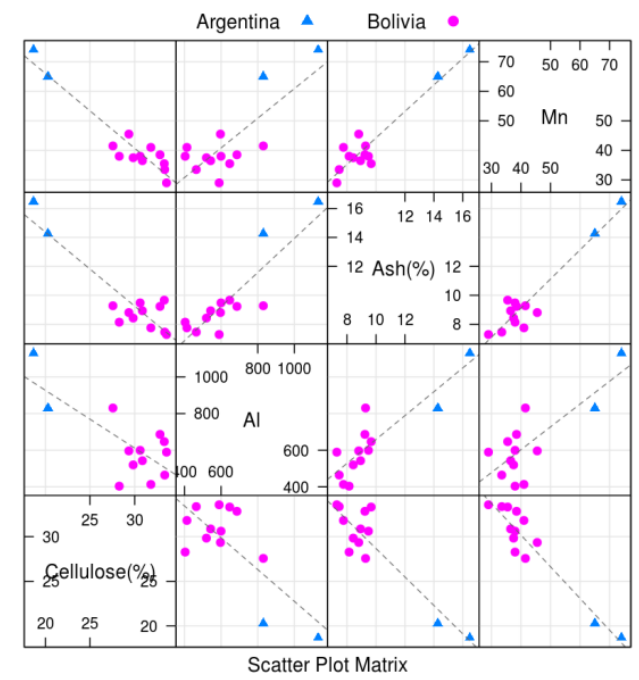

Fig 3. Scatter plot matrix of the four variables (cellulose, ash, manganese $(\mathrm{Mn})$ and aluminum (Al)) explaining the separation of the Bolivian ecotypes from the two cultivars from Argentina. 
Table 4. Geographic positions and altitudes of seed collection sites for Festuca ecotypes from Bolivia

\begin{tabular}{llllll}
\hline Accession & Origin & Locality & LAT (S) & LON (W) & ALT \\
\hline 9 & Cochabamba & Tiraque & $17^{\circ} 28^{\prime} 50.3^{\prime \prime}$ & $65^{\circ} 37^{\prime} 08.9^{\prime \prime}$ & 3673 \\
23 & Cochabamba & Melga & $17^{\circ} 25^{\prime} 33.2^{\prime \prime}$ & $65^{\circ} 54^{\prime} 57.4^{\prime \prime}$ & 3338 \\
38 & Cochabamba & Vacas & $17^{\circ} 31^{\prime} 03.0^{\prime \prime}$ & $65^{\circ} 36^{\prime} 48.2^{\prime \prime}$ & 3790 \\
41 & Cochabamba & Sunjani & $17^{\circ} 10^{\prime} 12.6^{\prime \prime}$ & $66^{\circ} 21^{\prime} 08.4^{\prime \prime}$ & 3974 \\
43 & Cochabamba & Parque Tunari & $17^{\circ} 16^{\prime} 15.9^{\prime \prime}$ & $66^{\circ} 19^{\prime} 49.7^{\prime \prime}$ & 3809 \\
19 & La Paz & Orkojipina & $16^{\circ} 31^{\prime} 44.2^{\prime \prime}$ & $68^{\circ} 20^{\prime} 53.7^{\prime \prime}$ & 3862 \\
21 & La Paz & Sica Sica & $17^{\prime} 19^{\prime} 05.1^{\prime \prime}$ & $67^{\prime} 46^{\prime} 02.7^{\prime \prime}$ & 3906 \\
27 & La Paz & Konchamarca & $17^{\prime} 22^{\prime} 29.8^{\prime \prime}$ & $67^{\circ} 27^{\prime} 27.5^{\prime \prime}$ & 3987 \\
10 & Oruro & Chilliwani & $17^{\circ} 37^{\prime} 51.6^{\prime \prime}$ & $67^{\circ} 13^{\prime} 45.6^{\prime \prime}$ & 3799 \\
29 & Potosi & Janco Huaje & $19^{\circ} 52^{\prime} 52.3^{\prime \prime}$ & $69^{\circ} 40^{\prime} 58.9^{\prime \prime}$ & 3659 \\
32 & Potosi & Cerro Potosi & $19^{\circ} 37^{\prime} 25.2^{\prime \prime}$ & $65^{\circ} 44^{\prime} 02.2^{\prime \prime}$ & 4316 \\
\hline
\end{tabular}

LAT (S) = latitude (south of Equator), LON (W) = longitude (West of Meridian), ALT = Altitude above sea level in meters.

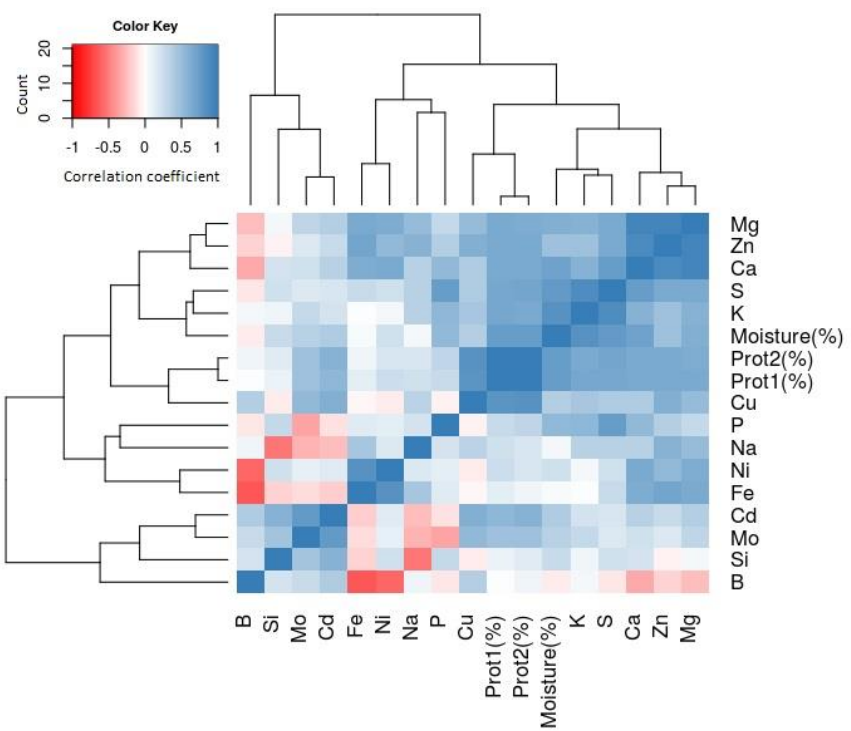

Fig 4. Heatmap showing the correlation between any of two variables measured in this study. Individual values contained in the matrix are represented as colors. The color intensity indicates the magnitude of the Spearman correlation coefficient either as positive (blue) or as negative (red).

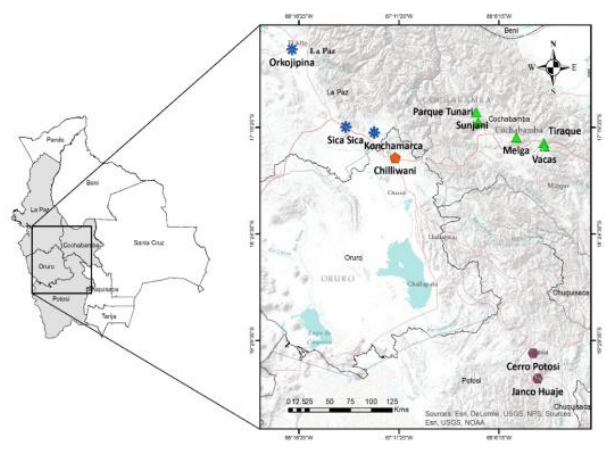

Fig 5. Map of the Plurinational state of Bolivia showing its nine departments (left) and collecting sites of seeds of Festuca ecotypes (right). (See Table 4 for further details). 
relatively low protein content. Sub-cluster IB comprised six ecotypes (accessions 10, 32, 23, 21, 43 and 29) having a relatively high content of protein and was further divided into three subgroups. The first subgroup included ecotypes of Oruro and Potosi (accession 10 and 32), the second subgroup included ecotypes from Cochabamba and La Paz (accessions 23 and 21) and the third subgroup included ecotypes from Cochabamba and Potosi (Accessions 43 and 29). Cluster II comprised of two Argentinian cultivars (Accessions 44 and 45) (Figure 2).

\section{Comparison of accessions based on their origin}

The results of the multivariate matrix of nutrient content and mineral data at $\log _{2}$ scale together with the Empirical Bayes and shrinkage methods favored a stable analysis under small sample size scenarios. These results were further confirmed after the analysis of variance showing significant differences based on the origin of the accessions, for cellulose $(P<0.001)$, ash $(P<0.001), \mathrm{Mn}(P<0.001), \mathrm{Mg}(P<0.001)$, Ni $(P=0.01)$, Fe $(P=0.02), \mathrm{Na}(P=0.03)$ and $\mathrm{Al}(P=0.04)$ (Table 1 , Table 2$)$.

\section{Principal component plot (PC) score-plots}

In order to determine the variables contributing to the clustering of accessions, a PC biplot on aggregated data was generated (Figure 1B). The interpretation of the results was made according to the direction of the vectors in the biplot. Accession 27, 38, 41 and 19 had a low content of protein, P, $\mathrm{Ca}, \mathrm{K}, \mathrm{S}, \mathrm{Zn}$ and $\mathrm{Cu}$. Accessions 21 and 29 were located almost at the end of the projected vectors corresponding to content of $\mathrm{Cu}$, Mo and $\mathrm{Cd}$, suggesting high content of these minerals. Accessions 44 and 45 corresponded to higher content of $\mathrm{Na}$, $\mathrm{Mg}, \mathrm{Fe}, \mathrm{Mn}, \mathrm{Al}, \mathrm{Ni}$ and ash content than the other accessions but had the lowest cellulose content. Accession 27 exhibited low protein and micronutrients content, while accession 43 had the highest B content. Protein content data obtained with the Kjeldahl method and the organic elemental analyzer were highly correlated as their vectors ended almost at the same point, indicating that both methods consistently measured the protein content.

A PCA on aggregated data was conducted to avoid overestimation of the significance since the two outliers (the Argentinian accessions 44 and 45) could influence the correlation between the nutrients. The results showed that cellulose, ash, $\mathrm{Mn}$ and $\mathrm{Al}$ account for the separation of the two Argentinian cultivars as outliers from the Bolivian ecotypes (Figure 3). Once these four variables were excluded in a new PCA, Spearman's correlation analyses were performed among the mineral data, nutritional content and moisture (Figure 4). The observed correlation coefficients were $\mathrm{Mg}-\mathrm{Ca}(r=0.94 ; P$ $<0.0001), \mathrm{Mg}-\mathrm{Zn}(\mathrm{r}=0.92 ; P<0.0001), \mathrm{Zn}-\mathrm{Ca}(\mathrm{r}=0.90 ; P<$ $0.0001), \mathrm{K}-\mathrm{S}(\mathrm{r}=0.86 ; P=0.0001), \mathrm{K}$-moisture $(r=0.83 ; P=$ $0.0004), \mathrm{Ni}-\mathrm{Fe}(r=0.83 ; P=0.0005), \mathrm{Cu}$-protein content $(r=$ $0.81 ; P=0.0006)$ and $\mathrm{S}-$ moisture $(r=0.77 ; P=0.002)$. Boron was negatively correlated to $\mathrm{Fe}(r=-0.65 ; P=0.0170)$ and $\mathrm{Ni}(r$ $=-0.58 ; P=0.0373)$, while Na was negatively correlated with $\mathrm{Si}$ $(r=-0.53 ; P=0.059)$. Molybdenum, $\mathrm{Ni}$ and $\mathrm{Cd}$ were either under the limit of detection or close to the limit of detection in all the analysed accessions, and hence it is difficult to make a conclusion due to their low values.

\section{Discussion}

Native forages in the highlands of Bolivia are important for the survival of Andean livestock producers (Genin and Alzérreca, 2006). Hence, information regarding the nutritional quality of the most important forages is essential to promote the recovery and development of grasslands. A few research reports on the nutritive value of Festuca dolichophylla and Festuca orthophylla in the highlands of Bolivia are available (Alzérreca and Lara, 1988; Genin et al., 1994; Alzérreca, 2004; Genin and Alzérreca, 2006; Condori, 2014). To the best of our knowledge, the present study may be, however, regarded as the most thoroughly undertaken analysis for this forage in Bolivia.

Genin et al. (1994) noticed $6.6 \%$ crude protein (in the rainy season) and $1.4 \%$ (in the dry season) for $F$. orthophylla. In addition, Genin and Alzérreca (2006) found $7.7 \%$ crude protein content in F. dolichophylla and $3.9 \%$ in F. orthophylla, while Mamani (2003) noted $3.7 \%$ protein in F. dolichophylla and $2.7 \%$ in $F$. orthophylla. A review presented by Alzérreca and Cardozo (1991) reported an average of $6.8 \%$ in F. dolichophylla and $4.2 \%$ in $F$. orthophylla. In the present study, the protein content of the ecotypes ranged from $6.1 \%$ to $12.4 \%$, which is slightly higher than in most previous reports.

According to the National Research Council (2007), the species and the maturity stage of the plants are among the major factors affecting the protein content in forages. Hence, these factors might have contributed to the discrepancies between the present and previous results, in addition to differences in the methods used.

Research by Villca and Genin (1995) regarding the feeding behavior of llamas and sheep when grazing concluded that both types of animals preferred $F$. dolichophylla (chilliwa) in the dry and rainy season. F. orthophylla (iru ichu) was, however, preferred by llamas throughout the year. Interestingly, accession 27 in the present study, which has been identified as F. orthophylla, had the lowest ash (7.3\%) and protein (about 6\%) contents, both of which were higher than those $(2.3 \%$ and $2.3 \%)$ reported by Mamani-Linares et al. (2013). The difference might be due to differences in the genetic background of the studied material, weather conditions and soil fertility, as reported in previous research (National Research Council, 2007; Merlo et al., 2018). According to Alzérreca and Cardozo (1991), the average value reported for ash content in F. orthophylla was $7.4 \%$, which is similar to our results for $F$. orthophylla (accession 27). MamaniLinares et al. (2013) reported $7.2 \%$ of ash content in $F$. dolichophylla whereas it was somewhat higher $(8.7 \%)$ in the Bolivian ecotypes (excluding accession 27 ) in the present study (Table 1).

Acid detergent fiber and neutral detergent fiber measurements are generally taken because both are based on the digestibility of the plant material, thus allowing the determination of how much energy animals receive from the consumed feed. Fiber that has higher cellulose, lignin and hemicellulose will typically take up more space in the stomach 
providing smaller amounts of energy to the animal. According to our results, the highest cellulose content was found in accessions 27, 9 and 19, which suggest a provision of less energy to animals.

Festuca arundinacea Schreb. and Festulolium constitute important sources of forage due to their nutritional value (Barnes, 2018; Macleod et al., 2013), thereby providing efficient forage production if climatic, edaphic and geographical factors are considered to support a sustainable agricultural practice.

The National Research Council (2007) reported 15\% protein content for Festuca arundinacea cv. KY 31 while Kaplan et al. (2017) reported $5.6 \%$ for cv. Olympus. These results are different from the ones presented in the present study, which were $7.7 \%$ and $6.8 \%$ of protein content, respectively, indicating substantial variation between cultivars.

The ash content reported for Festuca arundinacea cv. KY 3 by the National Research Council (2007) was 9\%, while Kaplan et al. (2017) reported $12.0 \%$ for cv. Olympus. The present study reported $16.5 \%$ for cv. 'Taita' again indicating variation between cultivars.

Meneses et al. (2017) reported $13.3 \%$ protein and $11.3 \%$ ash content in Festulolium while our results were $11.8 \%$ protein and $14.3 \%$ ash content, which might be explained by different soils and weather.

Minerals are separated into macrominerals, microminerals and trace elements according to the amount required by the animals. Hence, information on forage mineral supply is the starting point for an appropriate balanced mineral supplement ensuring optimal production, health and fertility in ruminants and camelids (National Research Council, 2007). Micronutrient content of forages depends on soil $\mathrm{pH}$ and fertility, forage species and maturity stage, season and climate, irrigation, and atmospheric inputs (McDowell et al., 1996; Givens et al., 2000). The variability of the micronutrients observed in the present study may be attributed not only to genetic differences but also to the interaction of all the factors just mentioned above. Eventhough the soil analysis was not performed in this study (due to financial limitations), previous reports showed that only a small fraction of micronutrients from soils are available to plants (Gupta et al., 2008). It is important to highlight that an acid soil $(\mathrm{pH}<6.0)$ may, however, limit absorption of $\mathrm{P}, \mathrm{K}, \mathrm{S}$, $\mathrm{Ca}, \mathrm{Mg}$ and Se while increasing absorption of $\mathrm{Fe}, \mathrm{Mn}, \mathrm{B}, \mathrm{Cu}$ and $\mathrm{Zn}$. In contrast, excesses of $\mathrm{Mo}$ and Se and deficiencies in $\mathrm{Fe}$, $\mathrm{Cu}, \mathrm{Zn}, \mathrm{B}$ and $\mathrm{Mn}$ can be found in forages grown in alkaline soils (National Research Council, 2007).

The macrominerals $\mathrm{Ca}, \mathrm{P}$ and $\mathrm{Na}$ are required for normal life processes (Hays and Swenson, 1985). Hence, their levels in forage grasses are important attributes to be considered. The previously reported amounts of $\mathrm{Ca}$ in forage grasses varies from 1890 to $3380 \mathrm{mg} \mathrm{kg}^{-1}$. Our results fit well into this range with the highest content of $\mathrm{Ca}$ in Festulolium (3375 $\mathrm{mg} \mathrm{kg}^{-1}$ ) and the lowest in accession 27 (1890 $\left.\mathrm{mg} \mathrm{kg}^{-1}\right)$. Phosphorus is required by ruminal microorganisms for digestion of cellulose (Burroughs et al., 1951) and synthesis of microbial protein (Breves and Schröder, 1991). Phosphorus content varies from 883 to $2140 \mathrm{mg} \mathrm{kg}^{-1}$ depending on the type of forage grass. Our results are within this range with the highest content noted in accession $45\left(2125 \mathrm{mg} \mathrm{kg}^{-1}\right)$ and the lowest in accession 27 (886 $\left.\mathrm{mg} \mathrm{kg}^{-1}\right)$.

Sodium along with $\mathrm{Cl}$ and $\mathrm{K}$, when found in proper concentration and proportion, are indispensable for a number of important functions in animals. The commonly reported range of $\mathrm{Na}$ in forage grasses is from 54 to $250 \mathrm{mg} \mathrm{kg}^{-1}$. In the present study, the $\mathrm{Na}$ content ranged from $54 \mathrm{mg} \mathrm{kg}^{-1}$ (accession 23) to $250 \mathrm{mg} \mathrm{kg}^{-1}$ (accession 45), and hence accessions that combine higher values for $\mathrm{Na}$ and other important mineral elements need to be considered for use in the Festuca breeding programs.

\section{Materials and methods}

\section{Germplasm and field experiments}

Eleven Festuca ecotypes from four Departments of Bolivia (Cochabamba, La Paz, Oruro and Potosi) (Figure 5; Table 4) and two cultivars $F$. arundinacea cv. 'Taita' and Festulolium from Argentina (kindly provided by Oscar Peman y Asociados S.A.) were used in this study. Field trials were conducted from December 2015 to January 2017 at the Centro Experimental Agropecuario Condoriri (CEAC; $17^{\circ} 31^{\prime} 41^{\prime \prime} S$ and $67^{\circ} 14^{\prime} 02^{\prime \prime} \mathrm{W}$ ), which is located approximately $50 \mathrm{~km}$ from the capital city, Oruro, and $12 \mathrm{~km}$ from Caracollo municipality at an altitude of 3830 masl. The average minimum/maximum temperatures registered at CEAC in the study period were $-1 / 19.8^{\circ} \mathrm{C}$ and the annual precipitation $159 \mathrm{~mm}$ with the heaviest rainfall of 59.8 $\mathrm{mm}$ registered in February (SENAMHI, 2016). Soil minerals were not measured in this study, however, soils in CEAC have been previously described by Mamani (2003) as alluvial and colluvial origin, with loam, sandy loam and clay loam textures with a $\mathrm{pH}$ average of 7.5 .

Seeds of each ecotype and cultivar were sowed in pots in May 2015 under greenhouse conditions and seedlings were transplanted to the experimental field (CEAC) in December 2015. The experimental design used was a randomized complete block design (RCBD) with 15 plants per ecotype/cultivar in two replications. The plants were spaced at $0.5 \mathrm{~m}$ within the rows and $1 \mathrm{~m}$ between rows. Plants were sufficiently watered during transplanting and when necessary during the experimental period. No fertilizer was applied during the experiment and plots were hand-weeded during September to May for two years.

\section{Sampling and nutritional analysis}

In January 2017, which is the beginning of the flowering period for fescues, leaves and florets from plants of each accession were cut using a stainless-steel knife simulating grazing height. Plant material of the same accession from the two replicates were mixed, weighed, kept in paper bags and transported to the laboratory of Centro de Alimentos y Productos Naturales (CAPN), Universidad Mayor de San Simón, Bolivia for nutritional analysis.

Water content of the plant material (which will be referred as moisture in this study), was determined in two technical replicates according to the standard air oven method 14.004 (William, 1984). Once the samples were dried and ground to a 
fine powder, nitrogen content was measured in two technical replicates using the Kjeldahl method 14.026 (William, 1984) and the organic elemental analyzer (Thermo Scientific Flash 2000) where the protein concentration was estimated as: $\%$ Protein $=\%$ Nitrogen $\times 6.25$. For the determination of ash and cellulose, method 14.006 and Kurschner method were used, respectively (William, 1984).

Mineral elements, Al, B, Ca, Cd, Cu, Fe, K, Mg, Mn, Mo, Na, Ni, $\mathrm{P}, \mathrm{S}, \mathrm{Si}$ and $\mathrm{Zn}$ were analyzed in two replicates using Inductively Coupled Plasma Optic Emission Spectrometry (ICP-OES + SS028311; Perkin-Elmer, OPTIMA 3000 DV) at the ICP laboratory of $A B$ Lennart Mansson International, Helsingborg, Sweden. The content of each element was calculated as absolute content in $\mathrm{mg} \mathrm{kg}^{-1}$.

\section{Statistical analysis}

Principal component analysis (PCA) was used to verify the reproducibility of the two replicates per accession and the use of their average values for all variables allowed us to characterize the variation among the accessions studied using aggregated data. In addition, clustering based on the unweighted pair group method with arithmetic mean (UPGMA) was used to examine the grouping of the accessions from Bolivia and the two cultivars from Argentina.

Spearman correlation coefficients were calculated between all variables. General linear models (limma Package, software R) were used to compare accessions by their region of origin in terms of the multivariate matrix of nutrient content and mineral data at the $\log _{2}$ scale. Empirical Bayes and shrinkage methods were used to borrow information across nutrients to make the analysis stable under small sample size scenarios, as described by Smyth (2005).

\section{Conclusion}

Even though Bolivian ecotypes did not show results comparable to Argentinian cultivars in terms of nutritional value, the results of this study provide important information about the nutritive quality of Festuca ecotypes from Bolivia for their further use in breeding for the highlands. It is important to highlight that protein content in accessions 29, 10, 21 and 32 were similar to Festulolium and higher than Festuca arundinacea. Additionally, they also showed high $\mathrm{Ca}$ and $\mathrm{Mg}$ content. On the other hand, accessions 38, 29, 23 and 21 showed high $\mathrm{P}$ content. Hence, these accessions could be good candidates for genetic improvement of these traits. Accession 27, which was identified as Festuca orthophylla had low protein, ash and micronutrients. Considering the fact that this species is widely distributed in the Bolivian highlands and that it is preferred by llamas, further research needs to be conducted on its genetic resources and those with increased nutritional values need to be incorporated in a breeding program for further improvement.

\section{Acknowledgements}

The authors thank the Swedish International Development Cooperation Agency (Sida), the Swedish University of
Agricultural Sciences (SLU) and Universidad Mayor de San Simón (UMSS) of Bolivia for the financial support for this study, and Centro Experimental Agropecuario Condoriri (CEAC) of the Universidad Técnica de Oruro for the field trials. Our gratitude also goes to researchers from the Centro de Investigación en Forrajes (CIF-La Violeta) of UMSS for their assistance with the field work and Dr. Gonzalo Durán-Pacheco for his kind cooperation on the statistical analysis.

\section{References}

Alzérreca H (2004) Campos nativos de pastoreo de Bolivia. In: Alzérreca H (ed) XV Reunión Nacional de Asociación Boliviana de Producción Animal (ABOPA), Oruro, Bolivia, pp 217-229.

Alzérreca H, Cardozo A (1991) Valor de los alimentos para la ganadería andina. Serie Técnica SR-CRSP/001. La Paz: IBTA, pp 32-35.

Alzérreca H, Lara R (1988) Evaluación de praderas nativas en el altiplano central y oeste del Departamento de Oruro. Primera reunión nacional en praderas nativas de Bolivia.

Programa de auto-desarrollo campesino, Corporación desarrollo de Oruro (PAC, CORDEOR). Oruro, Bolivia, pp 311.

Barnes RF (2018) Importance and problems of tall fescue. In: Kasperbauer $M$ (ed)Biotechnology in tall fescue improvement, $1^{\text {st }}$ edn. CRC Press, Boca Raton, Florida, pp 112.

Breves G, Schröder B (1991) Comparative aspects of gastrointestinal phosphorus metabolism. Nutr Res Rev. 4(1): 125-140.

Burroughs W, Latona A, DePaul P, Gerlaugh P and Bethke RM (1951) Mineral influences upon urea utilization and cellulose digestion by rumen microorganisms using the artificial rumen technique. J Anim Sci. 10 (3): 693-705.

Camino A, Sumar J (2000) Importance of alpacas and llamas in the changing context of development research. In: Tulachan PM, Saleem MAM, Maki-Hokkonen J, Partap T (eds). Contribution of livestock to mountain livelihood. Proceedings of the International Symposium on livestock in mountain/highland production systems: Research and

Development challenges into the next millenium, Pokhara, Nepal, 7-10 December 1999.

Campero JR (2004) Llama (Lama glama L.) and guanaco (Lama guanicoe M.): General perspective. In: Cardellino R, Rosati A, Mosconi C (eds) FAO-ICAR Seminar on camelids: Current status of genetic resources, recording and production systems in African, Asian and American camelids, Sousse, Tunisia, May 2004.

Condori G (2014) Caracterización bromatológica de especies forrajeras nativas (pastos y arbustos) de la ecoregión del altiplano, esenciales en la alimentación de los camélidos. Rev Cient Inv INFO-INIAF. 1(4): 68-80.

Geerts S, Raes D, Garcia M, Del Castillo C, Buytaert W (2006) Agro-climaticsuitability mapping for crop production in the Bolivian altiplano: A case study for quinoa. Agric For Meteor. 139 (3-4): 399-412.

Genin D, Villca Z, Abasto P (1994) Diet selection and utilization by llama and sheep in a high altitude-arid rangeland of Bolivia. J Range Manage. 47(3): 245-248. 
Genin D, Alzérreca H (2006) Campos nativos de pastoreo y producción animal en la puna semiárida y árida andina. Secheresse. 17(1): 265-274.

Givens DI, Owen E, Omed HM, Axford RFE (2000) Forage evaluation in ruminant nutrition. CABI Publishing, Oxon, UK, pp 345-397.

Gupta UC, Kening WU, Liang S (2008) Micronutrients in soils, crops, and livestock. Earth Front Sci. 15(5): 110-125.

Hays VW, Swenson MJ (1985) Minerals and bones. In: Dukes $\mathrm{HH}$ and Swenson MJ (eds) Physiology of domestic animals, $10^{\text {th }}$ edn. Wiley, New York, pp 449-466.

Kaplan M, Baser M, Kale H, Irik HA, Ulger I, Unlukara A (2017) Change in yield and chemical composition of tall fescue (Festuca arundinacea Schreb) plants under salt stress Turk J Field Crops. 22(2): 204-210.

Khan ZI, Ashraf M, Hussain A (2007) Evaluation of macro mineral contents of forages: Influence of pasture and seasonal variation. Asian-Aust J Anim Sci. 20(6): 908-913.

Lewis AJ, Bayley HS (1995) Amino acid bioavailability. In: Ammerman CB, Baker DH, Lewis AJ, (eds). Bioavailability of nutrients for animals: amino acids, minerals, and vitamins. Academic Press, New York, USA. pp. 35-65.

Mamani C (2003) Centro experimental agropecuario Condoriri. In: Meneses, R and Barrientos E (eds) Producción de forrajes y leguminosas en el Altiplano Boliviano.

Resumen de experiencias en seis años de trabajo entre el Centro experimental agropecuario Condoriri e instituciones del Fundo Universitario "La Violeta", Proyecto AgroLeg (CIATCIF-CIFP-SEFO) Cochabamba, Bolivia, pp 137-141.

Mamani-Linares W, Gallo C, Pulido R (2013) Composición botánica y contenido nutricional de pasturas nativas en periodo seco en el altiplano. Documento presentado en el XXXVIII Congreso Sociedad Chilena de Producción Animal. Libro de resúmenes. Instituto de Ciencia Animal, Facultad Ciencias veterinarias, Universidad Austral de Chile, Valdivia, Chile, 23-25 Octubre 2013.

Macleod C, Humphreys MW, Whalley WR, Turner L, Binley A, Watts CW, Skøt L, Joynes A, Hawkins S, King IP, O'Donovan S, Haygarth PM (2013) A novel grass hybrid to reduce flood generation in temperate regions. Sci Rep. 3:1683.

Markemann A, Stemmer A, Siegmund-Schultze M, Piepho HP, Valle-Zárate A (2009) State preferences of llama keeping functions in Bolivia. Livest Sci. 124(1-3): 119-125.

McDowell LR (1996) Feeding minerals to cattle on pasture. Anim Feed Sci Technol. 60(3-4): 247-271.

Martínez Z, Alzérreca H, Quispe JL (2004) Efecto de fertilización química y orgánica en la producción de forraje y altura de planta en chilliwa (Festuca dolichophylla). Memorias de ABOPA XV. Cochabamba, Bolivia, 51-62 pp.

Meneses R, Achá N, Salguero C (2017) Densidades de siembra en el rendimiento de forraje de Festulolium en el Centro de Investigación en Forrajes - La Violeta. Rev Agri Bol. 57: 9-16.
Mercado M, Arrázola S, Gutiérrez F, Ramírez K, Gonzales J, Atahuachi M, Vargas NJ,Burgos J, Ovando K, Campos $\mathrm{H}$ and Achá N (2013) Guía ilustrada de especies forrajeras nativas de la zona andina en Bolivia. Proyecto conservación y manejo sostenible de la biodiversidad de los recursos genéticos forrajeros de la zona andina de Bolivia. UMSS - FCAPFyV FcYT - CISTEL - BASFOR - CBG - CIUF-CUD, Cochabamba, Bolivia, $192 \mathrm{pp}$.

Merlo FE, Ku JC, Condori R, Pérez L, Albarracín A (2018) Efecto de la edad y época de año sobre el rendimiento y composición química del pastizal chilliwar Festuca dolichophylla en Tiahuanaco, Bolivia. In: Meneses R (ed) XXII Reunión Nacional de

Asociación Boliviana de Producción Animal (ABOPA), Santa Cruz, Bolivia, 11-13 Octubre, 2018.

Monteiro JAF, Hiltbrunner E, Körner C (2011) Functional morphology and microclimate of Festuca orthophylla, the dominant tall tussock grass in the andean altiplano. J FloraMorphol Distrib Funct Ecol Plant. 206 (4): 387-396.

Monteiro JAF, Körner C (2013) Leaf turnover and herbivory in the tall tussock grass Festuca orthophylla in the andean altiplano. Alpine botany. 123(1): 13-20.

National Research Council (2007) Nutrient requirements of small ruminants: sheep, goats, cervids, and new world camelids. The National Academies Press, Washington DC. DOI: $10.17226 / 11654$.

SENAMHI (2016) Record de estaciones. Servicio Nacional de Meteorología e Hidrología, Oruro, BoliviaSmyth GK (2005) Limma: linear models for microarray data. In: Gentleman R,Carey V, Dudoit S, Irizarry R and Huber W(eds) Bioinformatics and computational biology solutions using $R$ and bioconductor, $1^{\text {st }}$ edn. Springer, New York, pp 397-420.

Spears JW (1994) Minerals in forages. In Fahey CG Jr (Ed) Forage quality, evaluation and utilization. National Conference on Forage Quality, $1^{\text {st }}$ edn. Univ of Nebraska, Lincoln, Nebraska, USA, pp 281-311.

Sumar J (2010) Nutrition in camelids. In: Wittwer F, Chihuailaf R, Contreras H, Gallo C, Kruze J, Lanuza F, Letelier C, Monti G, Noro $M$ (Eds) Updates on ruminant production and medicine, XXVI World Buiatric Congress, Santiago, Chile, pp 343-357.

Villca Z, Genin D (1995) Uso de los recursos forrajeros por llamas y ovinos: Comportamiento alimenticio. In: Genin D. Picth H-J, Lizarazu R, Rodriguez T (eds) Rev. WAIRA PAMPA. Un sistema pastoril camélidos-ovinos del altiplano árido boliviano. ORSTOM. CONPAC-Oruro-IBTA, La Paz, Bolivia, pp 117-130.

William, S (1984) Official methods of analysis of the association of official analytical chemists, $14^{\text {th }}$ edn. William Byrd Press Inc, Virginia, $1141 \mathrm{pp}$.

Zapata A (2005) Las forrajeras nativas preferidas por los camélidos. Rev Suma Tama. 1: 1-20. 